\title{
Editorial dos organizadores deste número
}

A comunicação científica tradicional enfrenta uma série de barreiras que dificultam não apenas a publicação dos resultados de pesquisas, como também o seu acesso por parte da comunidade científica. Entre essas dificuldades, destacam-se: 1) alta excessiva no custo das assinaturas de revistas científicas; 2) longo prazo para a efetiva publicação de determinado artigo; 3) os direitos autorais são entregues gratuitamente aos editores científicos, os únicos a ganhar em toda a cadeia da comunicação científica.

A convergência tecnológica propiciou alternativas que podem derrubar parte dessas barreiras. Uma das alternativas que as tecnologias da informação e da comunicação propiciaram é o modelo de interoperabilidade denominado Arquivos Abertos (Open Archives). Em conseqüência, surge o movimento em prol do acesso livre à informação científica (Open Access). A experiência da conjugação dessa base tecnológica com o movimento do Acesso Livre à Informação Científica é o tema deste número especial da revista Encontros Bibli. As contribuições de especialistas brasileiros e estrangeiros para esta edição trazem um enfoque variado sobre este tema.

Iniciamos com uma entrevista com Stevan Harnad, um dos principais líderes do movimento do Acesso Livre à Informação Científica. Nessa entrevista, Stevan comenta sobre o papel do modelo de interoperabilidade Open Archives no movimento Acesso Livre à Informação Científica, falando sobre o futuro desse movimento e as suas estratégias para implantar o acesso livre à informação científica em todo o planeta.

O artigo "Comunicação científica: o papel da Open Archives Initiative no contexto do Acesso livre" aborda a questão do acesso livre, relacionando-a ao uso de tecnologias de auto-arquivamento e à publicação em periódicos eletrônicos que seguem a filosofia dos arquivos abertos como uma reação aos 
editores científicos comerciais. Apresenta as principais tecnologias de acesso livre e discorre sobre a necessidade do envolvimento de instituições acadêmicas e governos, principalmente no âmbito dos países lusófonos, na definição de políticas que suportem ações voltadas ao acesso livre.

Sob o ponto de vista tecnológico, é desenvolvido o artigo "Padrões para bibliotecas digitais abertas e interoperáveis". Seu autor apresenta os principais padrões, normas e protocolos de arquivos abertos e enfatiza a necessidade da adoção dos mesmos para que se possa obter a interoperabilidade entre sistemas de bibliotecas digitais funcionando em rede.

No contexto da educação a distância, é apresentado o trabalho "Comunicação científica em arquivos abertos e educação a distância no Brasil". Após mostrar o cenário das publicações sobre EAD em nível internacional e nacional, a autora analisa a publicação de EAD em arquivos abertos e recomenda o seu uso.

No artigo "Provedores de dados, provedores de serviços e periódicos em Ciência da Informação, Biblioteconomia e áreas afins", realiza-se um levantamento de tipos de repositórios e são analisados periódicos científicos on-line, mostrando que esta opção vem ocupando cada vez mais espaço na realidade do acesso livre. Seu objetivo é contribuir com a divulgação e uso destes provedores.

São apresentados também dois artigos que mostram aplicações das tecnologias de arquivos abertos. O primeiro refere-se à área de comunicação, com o trabalho "Repositório institucional em comunicação: o projeto Reposcom implementado junto à Federação de Bibliotecas Digitais em Ciências da Comunicação". O segundo enfoca as universidades católicas e se intitula "O acesso aberto à produção científica das universidades católicas: o caso da CVA-RICESU".

Em uma vertente mais reflexiva, encontra-se o texto "A produção científica disponível ao mundo: a tecnologia, a vontade e os acessos". Nele, a autora trata do acesso à informação sob a luz da evolução da tecnologia relacionada 
ao tratamento da informação e a vontade de obter conhecimento. Tece considerações quanto às bibliotecas tradicionais e digitais, assim como trata das iniciativas de acesso livre no Brasil e no mundo.

Desejamos boa leitura a todos!

Lígia Café (UFSC)

Hélio Kuramoto (IBICT) 